\title{
CLINICO-EPIDEMILOGICAL PROFILE OF HIV POSITIVE PATIENTS ON ANTI RETROVIRAL TREATMENT AT VIMS, BELLARY, KARNATAKA.
}

Ramesh K, Deepti N. Rao.

\author{
1. Assistant Professor, Department of Community Medicine, Vijayanagara Institute of Medical Sciences, \\ Bellary, Karnataka. \\ 2. Junior Resident, Department of Community Medicine, Vijayanagara Institute of Medical Sciences, Bellary, \\ Karnataka.
}

\section{CORRESPONDING AUTHOR}

Dr. Ramesh. K. MBBS, MD,

Assistant Professor, Department of Community Medicine,

Vijayanagara Institute of Medical Sciences (VIMS),

Bellary -583104, Karnataka, India

E-mail: ramspsm@yahoo.co.in

Ph: 00919481181291.

ABSTRACT: INTRODUCTION: In INDIA as stated by NACO people living with HIV/AIDS for the year 2009 estimates 23.1 lakhs which equates to a prevalence of $0.3 \%$. well this may seem low compared to large population of our country, a mere $0.1 \%$ increase in HIV prevalence would increase the estimated number of people living with HIV by over half a million. HIV epidemic is more severe in southern half of our country \& far north-east. In order to implement the desired intervention, epidemiology in a particular region has to be understood with regard to sociodemographic features, level of awareness as well as risk behavior of population.. This ARTC based study was planned with objective to find out profile of HIV positives so that this study may help in redesigning the strategy to bridge the gap between those detected and registered at ART centre. METHODOLOGY:

Study setting: ART centre, VIMS,Bellary,Karnataka,

Study period: Jan 2011 to Jun 2011,

Study subjects: HIV positive patients attending ART centre during study period,

Inclusion criteria: HIV positive patients on ART treatment at least for two years

Exclusion criteria: Patients not given consent and seriously ill

Sample size: 315

Sampling technique: Non probability purposive sampling

Data collection: Pre designed semi structured questionnaire was used to gather primary data by interview and case records as secondary data

Statistical tests: Proportion, Mean, Standard deviation, Paired ' $t$ ' test and Wilcoxon sign rank test

RESULTS: Study subjects included were 315 and out of them $52 \%$ were males \& $48 \%$ were females. The mean age of patients was $35+/-9$ years. The most common mode of transmission was heterosexual route (97.5\%). Only $61.7 \%$ were married and $46.5 \%$ were literate. Almost $50 \%$ of patients were coolie by occupation. The proportion of TB among HIV patient was found to be $22.5 \%$.The proportion of patients with WHO clinical stage at their first visit were $15.2 \%$ (I stage), $70.8 \%$ (II stage), 9.2\% (III stage) and 4.8\%(IV stage) but after two years of treatment, the stages were $-29.2 \%$ (I stage), $64.1 \%$ (II stage),5.4\% (III stage) and 1.3\%(IV stage) and this change was statistically significant. There was statistical significant difference for mean weight before $(46.3+/-10.3 \mathrm{kgs})$ and after $(54.5+/-19.3 \mathrm{kgs})$ the treatment and there was statistically significant improvement in mean CD4 count before $(156.9+/-7.6)$ and after(433+/-197) the 
treatment. CONCLUSION: TB was the most common opportunistic infection. The subjects showed significant improvement in CD4 count and average body weight after receiving ART.

KEY WORDS: HIV, ART, CD4

INTRODUCTION: According to the UNAIDS and WHO reports there are approximately 39.4 million people living with HIV/AIDS worldwide ${ }^{1}$. It is estimated that $90 \%$ of HIV infected persons live in the developing countries with Indian estimates being 5.1 million ${ }^{2,3}$. The first case of HIV/AIDS in India was identified in Chennai in 19864. And 24 years later, around 2.4 million Indians are HIV positive ${ }^{5}$.2Accordingto the National AIDS Control Organization HIV prevalence rate in India is $0.34 \%(0.25 \%-0.43 \%)^{6}$. As HIV treatment programs are implemented across the world, increasing numbers of HIV-infected persons are being treated with antiretroviral therapy (ART). In India, despite the fact that ART is provided free by the government, there are a large number of seropositive people who do not come forward to receive treatment. Non-adherence is another aspect even when they come for ART. These problems affect the overall success of the programme ${ }^{7}$.There is a need to study the profile of patients who come to ART centers and their clinical and socio demographic profile. Therefore, the study was conducted in order to understand the clinico-epidemiological profile of patients attending ART centers.

OBJECTIVE: To study the Clinico-epidemiological profile of HIV patients attending ART centre, tertiary care hospital, Bellary

METHODOLOGY: A descriptive study was conducted among HIV positive patients coming to the ART centre for seeking treatment at ART Centre, Vijayanagara Institute of Medical Sciences Bellary, Karnataka from Jan 2011 to Jun 2011. Totally 10,000 patients have registered and among them 5000 patients were on treatment at ART centre. Hence this study considered patients only who were on treatment. Totally 315 patients were included for the study. This sample size of 315 was based on number of patients attending ART centre during study period. These 315 patients were selected based on non probability purposive sampling technique with a purpose of patient who was on treatment for at least two years.

Data was collected using a pre designed semi structured questionnaire which contained information regarding socio demographic details and patient case records were reviewed to know clinical profile. After obtaining written informed consent, data was collected by interview technique and after the data collection health education was given to patients on Prevention \& treatment of HIV. Patients who were seriously ill and those who did not give consent were excluded from the study

Data was entered in Microsoft excel and analyzed in SPSS 15.

RESULTS: Totally 315 study subjects were included for the study and among them, 53\% were males\& $47 \%$ were females. Among total study subjects, more number of study subjects were in the age group of $26-35$ years (42.9\%). Among males, high proportion of study subjects were in 26 - 35 years $(40.7 \%)$ followed by 36 - 45 years(32.3\%) whereas among females high proportion of study subjects were in $26-35$ years (45.3\%) followed by 15 - 25 years(25.7\%) (Table.1)

Socio demographic characteristics of study subjects revealed that majority of patients were illiterates (53.7\%) and unskilled labours (49.5\%). Major portion of study subjects belong to a family size of 1 - 3 members (59.3\%). Nearly $30 \%$ of study subjects were widow (Table 2 ). 
This study explored the profile of the spouse of study subjects and it was found that $48.9 \%$ and $51.1 \%$ of spouse of study subjects were female and male respectively. It was also revealed that $45.9 \%$ of spouse of study subjects were positive for HIV and among them only $56.3 \%$ were on ART treatment (Table.3)

Major route of transmission of HIV among study subjects was heterosexual (97.8\%) and $22.5 \%$ of study subjects were co infected with Tuberculosis (Table.4).

Effect of ART was assessed among study subjects using WHO staging, Functional status, weight gain/loss and CD4 count before taking ART and after taking ART for at least 2 years. WHO staging and functional status were improved after taking ART and were found to be statistically significant. Effect was also observed drastically on CD4 count and weight improvement with statically significance (Table.5).

DISCUSSION: The present study revealed that males constituted $53 \%$ \& females $47 \%$ of the total study subjects which was almost near to National figures ${ }^{8}$. This is similar to the findings in a study conducted in the Udupi District by Kumar A et al ${ }^{9}$. Similar observation was made by Sarna A et al and Cauldbeck et al in Banglore ${ }^{10}$.Majority of the subjects belonged to the age group 26-45 years (69.2\%). Our study results were consistent with that of study by Cauldbeck et $\mathrm{al}^{10}$.The distribution according to marital status showed that married subjects constituted $62 \%$. In comparison with study done at Mangalore which had 58.45\% married patient registered, our study shows higher number of them registered at the ART centre ${ }^{11}$.This indicates more number of married patients taking ART at the centre and important role of PPTCT in the institution.

The distribution according to educational status showed that the sero-positivity was higher among the subjects with lesser education. These findings are similar to the study conducted by Jayaram $S$ et $\mathrm{al}^{12}$ and to that of the study conducted by Safren SA et $\mathrm{al}^{13}$ though the number of subjects with primary education was lesser than those with secondary education and above. But Cauldbeck et al observed no trends for education level with respect to the seropositivity ${ }^{10}$. In our study, maximum (49.5\%) patients were labourers, reveals more prevalence of HIV in this group of people. Low education status, migration and less awareness regarding safe sex can be the reason for high prevalence among this group of people. This result is higher than the study conducted by Kumar A et al $(44.5 \%)^{9}$. The reason for more number of attendees those were housewife can be gaining of infection by unsafe sex from their HIV positive husband or any other sexual partner. This point-out the unsafe sexual practices among married couple.

Tuberculosis was the most common opportunistic infections. These findings were similar to the study conducted by Sharma SK et al (71\%) in North India ${ }^{14}$ and Kumarasamy N et al in South India ${ }^{15}$ In our study, the health status of seropositives revealed improvement in the CD4 count, average body weight and functional status of the subjects after receiving ART indicating efficacy of ART .Pant Pai N et al in San Francisco also observed an improvement in CD4 cell counts after continuous ART therapy for HIV/AIDS ${ }^{16}$.

CONCLUSION: ART treatment has vital role in improving health of HIV patients as reflected by change in CD4 count and WHO clinical staging and more importantly there is no gender disparity in ART registration. 


\section{REFERENCES:}

1. Joint United Nations programme on HIV/AIDS (UNAIDS)/WHO, AIDS epidemic Update; December 2004, Geneva: UNAIDS/WHO, 2004.

2. Joint United Nations Programme on HIV/AIDS (UNAIDS)/World Health Organization (WHO), AIDS epidemic update; December 2000.Geneva: UNAIDS/WHO, 2000.

3. National AIDS Control Organization, Ministry of Health and Family Welfare, Government of India: HIV estimates in India.2004.

4. www.unicef.org/india/children_2358.htm (accessedon 27/10/2010)

5. Department of AIDS Control, Ministry of Health and Family Welfare, Government of India, Annual Report 2008-2009, National AIDS Control Organization, 2009

6. www.mohfw.nic.in/NFHS-3 HIV Prevalence.ppt (accessed on 27/10/2010)

7. Sarna A, Pujari S, Sengar AK, Garg R, Gupta I, Van Dam J. Adherence to antiretroviral therapy \& its determinants amongst HIV patients in India. Indian J Med Res 2008; 127:28-36.

8. NACO: National AIDS Control Programme Phase- III (2007-2012): strategy and implementation plan; Ministry of Health and Family Welfare; Govt. of India: 2006.

9. Kumar A, Kumar P, Gupta M, Kamath A, Maheshwari A, Singh S. Profi le of Clients Tested HIV positive in a Voluntary Counseling and Testing Center of a District Hospital, Udupi, South Kannada. Ind J Commu Med 2008; 33(3):156-9.

10. Cauldbeck MB, O'Connor C, O'Connor MB et al. Adherence to anti-retroviral therapy among HIV patients in Bangalore. India AIDS Research and Therapy 2009;6:7.

11. Badiger S, Thapar R, Mithra PP, et al. A profi le of patients attending an Anti Retroviral Therapy (ART) Centre at a tertiary care hospital in South India. AMJ 2010;3(6):344-348.

12. Jayaram S, Shenoy S , Unnikrishnan B, Ramapuram J, Rao M. Profi le of attendees in Voluntary Counseling and Testing Centers of a Medical College Hospital in Coastal Karnataka. Ind J Commuy Med 2008;33:43-6.

13. Safren SA, Kumarasamy N, James R, Raminani S, Solomon S, Mayer KH. ART adherence, demographic variables and CD4 outcome among HIV-positive patients on antiretroviral therapy in Chennai, India. AIDS Care 2005; 17:853-862. ]

14. Sharma SK, Tamilarasu K, Banga A, Goyal T, Bhatia I, Saha PK. Spectrum of clinical disease in a series of 135 hospitalised HIV-infected patients from north India. BMC Infectious Diseases 2004;4:52-61.

15. Kumarasamy N, Solomon S, Chaguturu SK, Cecelia AJ, Vallabhaneni S, Flanigan TP, Mayer $\mathrm{KH}$. The Changing Natural History of HIV Disease: Before and After the Introduction of Generic Antiretroviral Therapy in Southern India. CID 2005;41:1524-5

16. Pant Pai N, Estes M, Moodie EM, Reingold AL, Tulsky JP. The Impact of Antiretroviral Therapy in a Cohort of HIV Infected Patients Going in and out of the San Francisco County Jail. PLoS ONE, 2009; 4:e7115. SAARC

Table 1: Age sex wise distribution of study subjects

\begin{tabular}{|l|l|l|l|}
\hline AGE ( years) & MALE & FEMALE & TOTAL \\
\hline $15-25$ & $17(10.2 \%)$ & $38(25.7 \%)$ & $55(17.5 \%)$ \\
\hline $26-35$ & $68(40.7 \%)$ & $67(45.3 \%)$ & $135(42.9 \%)$ \\
\hline $36-45$ & $54(32.3 \%)$ & $29(19.6 \%)$ & $83(26.3 \%)$ \\
\hline$>45$ & $28(16.8 \%)$ & $14(9.5 \%)$ & $42(13.3 \%)$ \\
\hline TOTAL & $167(100 \%)$ & $167(100 \%)$ & $315(100 \%)$ \\
\hline
\end{tabular}


Table 2: Socio demographic characters of study subjects

\begin{tabular}{lll}
\hline Socio demographic characters & Frequency & Percentage \\
\hline Education & 169 & \\
Illiterate & 068 & $53.7 \%$ \\
Primary & 054 & $21.6 \%$ \\
High school & 024 & $17.1 \%$ \\
Pre university & & $07.6 \%$ \\
& & \\
\hline Occupation & 156 & \\
Unskilled & 084 & $49.5 \%$ \\
Semiskilled & 070 & $26.6 \%$ \\
Skilled & 005 & $22.2 \%$ \\
Professional \& others & & $01.5 \%$ \\
& & \\
\hline Family size & 187 & \\
1 - 3 & 121 & $59.3 \%$ \\
4 - 6 & 007 & $38.4 \%$ \\
$>6$ & & $02.2 \%$ \\
\hline Marital status & 195 & \\
Married & 092 & $61.9 \%$ \\
Widowed & 021 & $29.2 \%$ \\
Single & 007 & $06.7 \%$ \\
Divorcee & & $02.2 \%$ \\
\hline
\end{tabular}

Table 3: Profile of the spouse of study subjects

\begin{tabular}{lll}
\hline Profile & Frequency & Percentage \\
\hline Age group & & \\
15 - 25 years & 084 & $28.5 \%$ \\
26 - 35 years & 140 & $47.6 \%$ \\
36 - 45 years & 065 & $22.1 \%$ \\
$>45$ years & 025 & $08.5 \%$ \\
\hline Sex of spouse & & \\
Female & 144 & $48.9 \%$ \\
Male & 150 & $51.1 \%$ \\
& & \\
\hline HIV status of spouse & & \\
Positive & 135 & $45.9 \%$ \\
Negative & 069 & $23.4 \%$ \\
Unknown & 090 & $30.6 \%$ \\
& & \\
\hline Spouse on ART & & $56.3 \%$ \\
Yes & 076 & $43.7 \%$ \\
No & 059 & \\
\hline
\end{tabular}


Table 4: Risk factor Profile of study subjects

\begin{tabular}{lll}
\hline Variables & Frequency & Percentage \\
\hline Mode of transmission & 308 & \\
Heterosexual & 007 & $97.8 \%$ \\
Others & & $02.2 \%$ \\
& & \\
\hline History of tuberculosis & 071 & $22.5 \%$ \\
Yes & 244 & $77.5 \%$ \\
No & & \\
& & \\
History of Smoking & 087 & $27.6 \%$ \\
Yes & 228 & $72.4 \%$ \\
No & & \\
& & \\
\hline History of Alcohol & & $27.6 \%$ \\
Yes & 087 & $72.4 \%$ \\
No & 228 & \\
\hline
\end{tabular}

Table 5: Effect of ART on WHO staging, functional status, weight and CD4 count among HIV patients

\begin{tabular}{|c|c|c|c|}
\hline EFFECT OF ART ON & $\begin{array}{l}\text { AT 1 } 1^{\text {st }} \text { VISIT(before } \\
\text { ART) }\end{array}$ & AFTER 2 years & P VALUE \\
\hline 1) WHO STAGING & & & \multirow{5}{*}{$\begin{array}{l}0.00 \text { (Wilcoxon } \\
\text { Sign Rank test) }\end{array}$} \\
\hline STAGE 1 & $48(15.2 \%)$ & $92(29.2 \%)$ & \\
\hline STAGE 2 & $223(70.8 \%)$ & $202(64.1 \%)$ & \\
\hline STAGE 3 & $29(9.2 \%)$ & $17(5.4 \%)$ & \\
\hline STAGE 4 & $15(4.8 \%)$ & $4(1.3 \%)$ & \\
\hline \multicolumn{4}{|l|}{ 2) FUNCTIONAL STATUS } \\
\hline BEDRIDDEN & $9(2.9 \%)$ & nil & \multirow[t]{3}{*}{$\begin{array}{l}0.02 \text { (Wilcoxon } \\
\text { Sign rank test) }\end{array}$} \\
\hline AMBULATORY & $49(15.6 \%)$ & $2(0.6 \%)$ & \\
\hline WORKING & $257(81.6 \%)$ & $313(99.4 \%)$ & \\
\hline $\begin{array}{c}\text { 3)WEIGHT OF } \\
\text { PATIENT(mean weight) }\end{array}$ & $46.3+/-10.3 \mathrm{~kg}$ & $54.5+/-19.3 \mathrm{~kg}$ & $\begin{array}{l}0.01 \text { (Paired 't' } \\
\text { test) }\end{array}$ \\
\hline $\begin{array}{c}\text { 4)MEAN CD4 } \\
\text { coUNT(cells/ml of blood) }\end{array}$ & $156.9+/-7.6$ & $433+/-19.7$ & $\begin{array}{l}0.00 \text { (Paired ' } \mathrm{t} \text { ' } \\
\text { test) }\end{array}$ \\
\hline
\end{tabular}

